\title{
CONTRASTING APPROACHES TO LITHIC ASSEMBLAGES: A VIEW FROM NO MAN'S LAND
}

MIRCEA ANGHELINU,

LOREDANA NIȚĂ,

CRISTINA CORDOȘ

\begin{abstract}
:
Abundantly preserved in the prehistoric archaeological record, lithic tools enjoyed a preferential focus aimed at understanding Palaeolithic cultural and adaptive variability. However, approaches to lithic variability are often framed in contrasting theoretical and methodological moulds, with the (predominantly analytic) Anglo-American and (preferentially synthetic) French research traditions viewed as providing paradigmatic examples of mutually incompatible perspectives. By stressing the strong points of each research tradition, and using an Upper Palaeolithic case study in Romania, the paper highlights the potential of a more productive, pragmatic stance, in which each type of approach is seen as contributing with equally instructive, complementary information.
\end{abstract}

\section{REZUMAT: ABORDĂRI ANTAGONICE ALE ANSAMBLURILOR LITICE: O PERSPECTIVĂ DIN TĂRÂMUL NIMĂNUI}

Uneltele litice, prezente din abundență în materialul arheologic, au constituit domeniul preferat de studiu pentru înțelegerea variabilității culturale și adaptative paleolitice. Adesea, abordarea variabilităţii litice a fost construită pe tipare teoretice și metodologice contrastante, în care tradițiile de cercetare anglo-americane (predominant analitice) şi franceze (mai ales sintetice) au fost percepute drept sursele unor exemple paradigmatice ale unor perspective reciproc incompatibile. Subliniind punctele forte ale fiecărei tradiții de cercetare, articolul de față evidențiază, pornind de la un studiu de caz extras din paleoliticul superior din România, potențialul unei poziționări pragmatice, mai productive, în care contribuția fiecărui tip de demers este privită ca fiind la fel de instructivă, oferind informații complementare.

KEYWORDS: Upper Palaeolithic, theory, methodology, lithic technology, variability.

CUVINTE CHEIE: paleolitic superior, teorie, metodologie, tehnologie litică, variabilitate.

\section{Introduction}

Archaeology has always put a lot of emphasis on things, usually as a mean of telling something relevant about their authors. In the traditional culture-history, material culture was speaking loud (or just whispering) about human ideas, intentions, mental templates or social identities; in processual archaeology, a lot of human material creation was functional/adaptive in its essence; the post-processual atmosphere imbued with „,meaning” everything, from landscape features to pottery fragments; more recently, „the new materialism”, in an attempt of abandoning the anthropocentrism which, among others, made archaeology possible, added a new twist to this inborn archaeological tendency of cherishing things ${ }^{1}$. Fortunately, most archaeologists today still believe that material things, especially artefacts, are important because they tell something about their makers. Put differently, they do mean something. What exactly are those meanings and how relevant are certain categories of artefacts for the questions asked today about the past is of course a matter of fierce discussion.

Whatever their position on these theoretical matters, archaeologists are nevertheless biased in sorting the things

${ }^{1}$ e.g. Olsen 2012; Witmore 2014. 
of relevance: pottery is often taken as more relevant for Neolithic archaeological research than, say, sub-modern contexts. For Palaeolithic archaeology, lithics clearly hold the centre stage. They are not only abundant and well preserved, but they are also often the sole strain of evidence surviving from the people in the remote Ice Age times. Therefore, many questions asked about those people (technological, aesthetic or cognitive capabilities, environmental knowledge, social and identity issues, subsistence, mobility, etc.), rely on lithic knowledge. Although there is a wide agreement regarding the heuristic importance of lithics as a source of knowledge about Palaeolithic people and their lives, lithics themselves obviously cannot tell archaeologists how important they really were in their original contexts: their haphazard survival cannot thus be automatically equated with their actual relevance ${ }^{2}$. There are in fact strong ethnographic evidences indicating that organic materials provide a far more important technological support for recent prehistoric hunter-gatherers in both warm and cold environments ${ }^{3}$ and there is no particular reason to think things were much different in Palaeolithic times ${ }^{4}$. To assess the role lithics played, various other contextual evidence is thus needed (e.g. alternative technologies or knowledge, environmental circumstances, functional contexts etc.). This information is either difficult to gain on the proper temporal scale (e.g. environmental data) or depends itself on the study of lithic tools (e.g. functional analyses, traceology etc.). The resulting paradox is evident: one needs to assess the very relevance of lithics in archaeological contexts mostly composed of... lithics. Fortunately, apart from directly relevant additional contextual data, there are other ways of dealing with this paradox, like bringing in experimental or ethnographic knowledge that help framing the information brought by lithics themselves. It is precisely this additional knowledge, strongly related to peculiar cultural and academic traditions, which in fact structures lithic analyses and lead to highly contrasting perceptions of what lithics mean and tell to modern inquirers.

Apparently, for making sense of lithics, most Palaeolithic archaeologists need to choose between a French way and an Anglophone (especially American) way ${ }^{5}$. This is not to say that, despite their reputation and academic authority, these are the only options available on the market: for instance, many Palaeolithic researchers in Central or Eastern Europe, defending their own disciplinary legacies, would find these ways theoretically inflexible, methodologically costly or simply unsuited for solving all intricacies involved in lithic interpretation. Nonetheless, the major influence these traditions currently exert on the Palaeolithic research worldwide is beyond doubt. Coupled with an ample theoretical and methodological coverage, this pre-eminence suggests that any discussion on the French/ Anglophone divide in lithic studies would touch upon issues or relevance for most Palaeolithic researchers.

\section{The big divide}

The largely acknowledged Anglo-American/French divide in lithic studies is actually very old, going back at least to the notorious Bordes/Binford clash ${ }^{6}$. As brightly demonstrated in a recent comprehensive review ${ }^{7}$, the conflict goes beyond the commonly recognised paradigmatic differences ${ }^{8}$ or the equally notorious contrasting academic cultures $^{9}$, to the very epistemological roots and world-views feeding the Western scholarship.

To cut a very long and interesting story short, using S. Pepper's ,world hypotheses” made operational by S. Hussain, it seems that the highly analytical Anglo-American tradition favour either 'formistic' or more theoretically-guided „mechanistic” explanations; in both cases, the „parts”, usually as small as lithic attributes, are used to build the „whole" (the assemblage) a bottom-up perspective fundamental for a scientifically-grounded interpretation of lithic production. In any case, as ,,populations of artefacts”, each placed on an equal analytic footing, lithics are quantitatively, almost democratically exposed to an etic reading. Clearly articulated theoretical premises or hypothesis, coupled with explicit, replicable and usually quantitative methodologies are typically associated to this research philosophy. Theory is clearly separated and formally precedes the interpretation of „data” or empirical „facts”.

In the French milieu of lithiciens, „contextualist” and „organicist” explanations are by far preferred. In its penchant for a holistic treatment of lithic assemblages, this tradition looks for emergent properties or rule-guided schemes of lithic production, documenting particular technological lineages, individual or collective savoirfaire, and contextual options; the importance of each part is strongly dependent on the „whole" under scrutiny.

\footnotetext{
$\overline{2}$ Anghelinu, Niță 2009.

${ }^{3}$ Kelly 2013.

${ }^{4}$ e.g. Hayden 2015.

${ }^{5}$ Hussain 2019.

${ }^{6}$ Sackett 1991.

${ }^{7}$ Hussain op cit.

${ }^{8}$ Clark, Lindly 1991; Clark 2009.

${ }^{9}$ Coudart 1999.
} 
As those „wholes” vary a lot, the resulting approaches are therefore almost by definition qualitative, and often hardly replicable. Voicing mental templates aimed at a certain tool design, lithics almost naturally ask for an emic reading. Already inherent to the functional labelling of early typologies (pointes, couteaux, racloirs, etc.), such emic interpretations grew orders or magnitude stronger in the more recent, technologically-oriented approaches. Stage-like descriptions of technological choices are the hallmark of these approaches, usually built in a dialecticaldialogical logic and corroborated by contextual evidence. Although driven by a problem-solving philosophy of research, the French-styled approaches do not rely on a specific (e.g. middle-range) theory of lithic production. "Theory" comes, if at all, only after the empirical evidence is assessed.

(Over)simplifying the much deeper and elegant analysis proposed by S. Hussain, what is apparently opposing is thus a rather rigid, formal, non-narrative logic to an overtly hermeneutic, dialogical approach. Philosophically, the opposition may be of course captured in other terms, like quantity vs. quality, analytic vs. synthetic, universalism $v s$. particularism, forms vs. essence, even nature vs. culture, but these dichotomies are obviously too vague to provide an immediate grasp on the many practicalities of lithic studies.

Leaving these high epistemological grounds, it appears that for the Anglo-American tradition lithics are mostly „pieces of stone”, expressing constraints pragmatically related to function, mobility, raw material accessibility, duration of use, recycling, abandonment etc. This is not to say that „culture” (i.e. socially learned technological traditions) does not matter, but just that the importance or factual visibility of these „traditions" in lithic matters are often blurred by more mundane mechanical constraints, cost-benefit calculations and other practical urges. Echoing L. Binford's disavowal of ,,paleo-psychology”, what exactly had in mind our Palaeolithic ancestors seems less relevant, or scientifically untreatable: the important issue is their actual behaviour and its effect on the surviving material remains. Culture looks more like a „residue” showing up when behavioural ecology's optimality is not met. Lithics are an essential interface of environmental adaptation, a concept to be constantly found, though in very different guises, in most Anglophone literature on Palaeolithic times. Furthermore, though this is not necessarily acknowledged by all English-speaking specialists and for all lithic products ${ }^{10}$, most lithic artefacts are generally seen as easy to make, reshape, recycle and replace; ,types” are just conventional breaks in an otherwise fluid process of reduction ${ }^{11}$. Blending a deep respect for natural sciences, a strong infusion of modern hunter-gatherer ethnography, a deep belief in uniformitarian principles and a strong materialist stance ${ }^{12}$, the Anglophone tradition seems thus interested in very ,theoretical” and pragmatic humans - for in contrast to some other qualities (like aesthetic sense or manual ability), their (assumed) pragmatism is easiest and safest to be quantified by rigorous scientific means.

For the French family of approaches, lithics are material creations related above all to individual capabilities/ choices, technological know-how and socially learned traditions. Cultural inertia largely overweighs ${ }^{13}$ most circumstantial constraints (raw material accessibility, function, mobility etc.), although it is largely admitted that lithic variability is multi-scalar and cannot be explained based on single causes (function, length of occupation, tradition etc.). Lithic objects are anything but simple pieces of stone or „fallout of adaptation”; on the contrary, they are ,projects”, so the subtle complexities of lithic production are usually emphasized. If there is an adaptation, it seldom refers to environmental challenges, always viewed as socially mediated, but mostly to the inner dialectics between innovation and the inherited technological knowledge. If there is a theory, it is deeply embedded and inseparable from practice. Deeply grounded in social sciences and humanities, the French phylum defends a particular sense of alterity, treating prehistoric worlds as being by definition alien from the ethnographic present; consequently, it also prefers ,,abstract”, intelligent though perhaps conservative, Palaeolithic humans, with which initiates a more intimate, dialogical relationship. Subjectivity and the human factor are here a natural part of the scientific inquiry.

Pointless to stress, the above description of the debate cannot capture the variety of arguments defended by each side $^{14}$. The point, however, is that although no approach can be considered as a priori weaker in epistemological terms, the theoretical thrust and the related methodological extensions are clearly opposed. There are so many contentious points between the two traditions of thought and practice, that identifying a common ground seems daunting if not impossible. Apparently, the only point on which most specialists agree, except for the obvious need of a complete recovery from the field, is that lithic assemblages convey various information (technological, economical/functional, social, cognitive etc.) regarding their makers. However, the importance/relevance/visibility

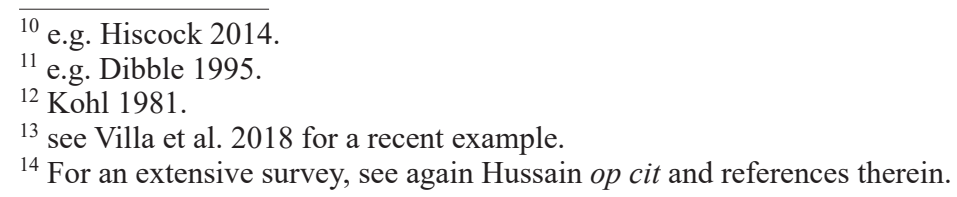


of each of these aspects on the content, size and specific features of the assemblages is postulated very differently and depends massively on each lithic analyst's educational or paradigmatic background.

Our goal here is neither to plead for one of the two perspectives, nor to attempt at blending them, for their premises are irreducible in many ways. From the point of view of an East-Central European rather poorly structured academic tradition of Palaeolithic research, where both French, German, Anglophone and even Russian influences were variably felt by the local Palaeolithic research ${ }^{15}$, both constellations seem to have their strengths and limits. We therefore wondered whether our ,peripheral wisdom” from such a „no man's land” and a case-study may add something useful to the debate. In our view, both perspectives listed above add a lot to archaeological knowledge; they act in rather complementary ways, provided that the (1) based on all contextual data, the general technological system involved is acknowledged, (2) the range of questions asked is clearly defined, and (3) the temporal scale of the resulting narrative is properly defined.

\section{One size does not fit all}

Even a superficial look at the Palaeolithic record rapidly suggests that both families of approaches may score low in some particular Palaeolithic contexts. The main reason is that, despite claims to the contrary ${ }^{16}$, both schools have to rely on some sort of uniformitarian thinking, be it Holocene hunter-gatherer/homo economicus, or some abstract, universal human rationality. What if the uniformitarian principle betrays?

The variable status of lithic technology in a particular society or culture-evolutionary stage, for that matter, can make a huge difference and the enormous differences recorded in terms of lithic innovations/stasis provide cautionary notes ${ }^{17}$. For instance, it does matter whether the Lower Palaeolithic humans before the Acheulean were obliged, habitual or simply occasional lithic tools users ${ }^{18}$. Each possibility carries huge consequences for it may ruin or strengthen either the ethnographically-grounded adaptive models (the Anglophone way), or the more abstract tracking of technological lineages based on learning/teaching (the French way).

Although paradigmatically connected to the functional readings promoted by the Anglophone school since L. Binford, the European Mousterian lithic technology, poorly correlated to climatic gradients ${ }^{19}$ and thus defying ethnographic expectations ${ }^{20}$, raises equally thorny questions. Possible explanations for this mismatch are either a marginal role of lithic tools played in Neanderthal adaptation (i.e. use of ,soft' technologies, that is, knowledge ${ }^{21}$, or other, perishable „hard” technologies ${ }^{22}$ ) and/or an unusual weight of learned traditions ${ }^{23}$, able to overwrite more practical, circumstantial requirements. Either way, in many if not all cases, measuring ,adaptive” responses as if they were directly expressed in lithics shape or assemblage structure is most likely wrong: beyond the formation processes that need to be accounted ${ }^{24}$, various other sociotechnical ${ }^{25}$ settings need to be imagined.

\footnotetext{
${ }^{15}$ Anghelinu 2003; Anghelinu 2006.

${ }^{16}$ While French Palaeolithic researchers regularly state the deep discontinuity separating „fossil” prehistoric societies from historical ones, the Anglophone tradition usually use the hunter-gatherer „holotype” to stress their own understanding of alterity of Palaeolithic lifestyles (cf. Hussain op cit, passim). Unfortunately, alterity presupposes by definition some universal/uniformitarian features to be measured against. These universals may range from the simple human predisposition to symmetry to the mathematically elaborated rules of behavioural ecology - but they are inevitably present.

${ }^{17}$ See for instance the Chinese Palaeolithic record defying all the acknowledged chrono-cultural units in Western Eurasia, perhaps in connection to different environmental challenges/affordances (Gao 2013).

${ }^{18}$ Hiscock op cit.

${ }^{19}$ Kuhn, Stiner 2001.

${ }^{20}$ Torrence 2001; Kelly op cit.

21 „It seems that the realm in which Middle Palaeolithic behavioural complexity is best illustrated is resource planning and the degree of mobility of the populations of hunter-gatherers within the territory" (Meignen Delagnes, Bourguignon 2009, 20).

${ }^{22}$ sensu Kelly op cit.

${ }^{23}$ The spatial and chronological patterning of some techno-typological lineages, like the European Micoquian or the Levantine Mousterian (Richter 2000; Hovers, Belfer-Cohen 2018), can hardly be explained by a recurrent reactivation of similar adaptive circumstantial choices, although tracking similar lineages across the entire Middle Palaeolithic interval constantly failed (Kuhn 2013). If real (cf. Bar-Yosef, Van Peer 2009), the (excessive?) complexity of Levallois technology, coupled with apparently equally long-lived, rather straightforward flake technologies in many other Mousterian contexts, is equally puzzling. ,[V]ariability in material culture (inclusive of stone tools) is not linked exclusively to functional considerations (...) Tool designs should be considered in the context of the reduction sequences that produced them and the dynamics of transmission of those reduction sequences across generations. Moreover, functional traits often bear symbolic meanings that are as important as the function itself. «Technological recipes» may be persistently favoured in inter-generational transmission due to their functional benefits, but also because of conservatism, anti-novelty bias, or biases related to the status of the model from which the variant is learned rather than to its functional properties (Hovers, Belfer-Cohen op cit).

${ }^{24}$ Shott 2010.

${ }^{25}$ Sensu Pfaffenberger 1992.
} 
Many aspects seem also to depend on the general lithic production system involved and it is no accident that many paradigmatic clashes between the two research traditions are related to Lower Palaeolithic or to Middle Palaeolithic/ Mousterian case-studies. Dissolving the French-styled typological essentialism and stage-like understanding of lithic production, together with its emic footing, may indeed work on the allometry-prone reduction of the Lower Palaeolithic handaxes ${ }^{26}$ or to the Middle Palaeolithic flake-based industries, where the artefacts' life-uses and their migration between various typological categories is reasonably demonstrated ${ }^{27}$. It may also work well on ethnographic case studies from warmer environments ${ }^{28}$. Such readings would be, however, much more difficult to defend in the case of European Upper Palaeolithic (hereafter UP) industries associated to temperate and cold environmental contexts.

With carefully mastered lithic technologies, a high-degree of standardization, raw material transfers constantly exceeding $150 \mathrm{~km}$ and reaching to $700 \mathrm{~km}^{29}$, many of the doubts above, like the strict dependence of humans on lithic tools or the related importance of extensive learned knowledge, simply dissipate. This is not to say that the closer ethnographic range of the UP and the modern human authorship of (most) UP industries dissolves the big divide into agreement, for it clearly does not ${ }^{30}$. The Anglophone tradition maintain that all traditional typologies level the duration of use of each artefact to secure their typological „essence” ${ }^{\prime 3}$. Explicitly or not, the French opponents suggest that the negative effects of this typological essentialism are considerably reduced in UP times. At least some if not most UP artefacts (and not only the famous Solutrean leaf points) point to deliberate and explicit templates, even though they may be further open to allometric changes - an endscraper will generally stay an endscraper despite its continuous reduction, and this may well be the case with most burins; even if prone to subtle typological changes, the small hafted armatures with backed edges will maintain their general morphology and will be recognized as such irrespective of subtle typological changes that may be (abusively) used as indexfossils for paleo-cultural units ${ }^{32}$.

The „special status” of UP lithic industries cherished by the French/European continental tradition is, of course, programmatically refused by the Anglophone counterpart, for which the formation of lithic assemblages, following uniformitarian rules, is essentially the same ${ }^{33}$ irrespective of time or space, especially when a quantitative/ diachronic perspective is taken ${ }^{34}$. In the following we propose a closer look at three chronologically distant UP lithic assemblages recovered from the same open-air site in Eastern Carpathians. Our aim is to see how the two apparently opposing perspectives work on empirical grounds.

\section{A case study: lithic assemblages at Bistricioara-Lutărie III}

Three chronologically distant, well-segregated UP lithic assemblages were selected for a convergent look through the lenses provided by the two research philosophies, formally opposed as the analytic/quantitative vs interpretative/ qualitative dichotomy ${ }^{35}$. The lithic assemblages (hereafter, LA1, LA2, and LA3) discussed here were uncovered between 2015 and 2019 in the multi-layered UP open-air site at Bistricioara-Lutărie III (Ceahlău Basin, Eastern

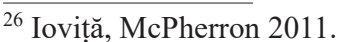

${ }^{27}$ Dibble op cit.

${ }^{28}$ For a case study in which nor the function, neither the ethnic identity but the raw material economy decided the lithic assemblages' componence, see Hiscock 2009. The idea of a tool box related to a strict functional typology proved repeatedly false, since even the paradigmatic burins and endscrapers could have multiple functions (Andrefsky 2005). Moreover, ethnographic examples (at least in warm environments like Australia and New Guinea) of a complete lack of consideration for the final shape of a lithic product and a pragmatic interest only in the active edge/angle, weight or prehensility could be terrifying for archaeologists' functional typologies (see Holdaway, Douglas 2012). Some populations do not envision lithic artefacts as a clearly defined production objective, but as lithic fragments useful in complying with immediate necessities. Nevertheless, there is generally a good correlation between climate, risk and technological complexity (e.g. Torrence 2001, Fitzhugh 2001), which makes most ethnographic examples from warm environments rather irrelevant for the European Upper Palaeolithic, for instance.

${ }^{29}$ Féblot-Augustins 2009.

${ }^{30}$ Hussain op cit.

${ }^{31}$ Shott op cit.

${ }^{32}$ Barton, Neeley 1996.

${ }^{33}$ The determinant factors ,among others' for the componence/accumulation of all lithic assemblages are the spatial and temporal distribution of raw material, its qualities, the mobility patterns related to lithic procurement and transport, production techniques, the lithic tools use, the behaviours related to their abandonment etc.; there are few „specially designed” tools, their stages (i.e. new, used, retouched, exhausted) being the same for most part of the assemblages. The technological system is thus held constant, with major effects in assessing the utility of the transported lithic tools (Barton, Riel-Salvatore 2014)

${ }^{34}$ Barton, Riel-Salvatore op cit.

${ }^{35}$ Hussain op cit.; Perlès 2016.
} 
Carpathians) ${ }^{36}$. The archaeological contexts of each assemblage yielded relatively large flat sandstone plaquettes and pebbles, combustion features, and few heavily weathered organic remains. LA2 and LA3 assemblages were recorded, although with variable density, on the entire excavated surface $(25 \mathrm{sqm})$, and were each associated to accumulations of anthropogenic features ca. $20 \mathrm{~cm}$ thick, therefore came from comparable volumes of sediment. LA1 comes from a dense, ca. $30 \mathrm{~cm}$ thick palimpsest accumulation, excavated however on a much smaller surface $(4 \mathrm{sqm})$. The numerical chronology (AMS radiocarbon and thermoluminescence on burnt flint) indicate distinct accumulation episodes of very different duration: 15-19 ka cal BP (LA1), $23 \mathrm{ka} \mathrm{cal} \mathrm{BP(LA2),} \mathrm{and} 27 \mathrm{ka}$ cal BP (LA3) respectively. The characterization of the three lithic assemblages rely solely on the lithic data and ignore for now the cultural labelling (Gravettian, early Epigravettian, and Epigravettian, respectively) to which we will return later.

LA3 represents one of the oldest consistent evidence of human presence in the Ceahlău Basin. $92.87 \%$ of the slightly over 2200 items lithic assemblage consist of allogenous (i.e. ca $150 \mathrm{~km}$ to the $\mathrm{NE}$ as the crow flies) Cenomanian/Turonian flint from the Prut-Dniester interfluve. The remaining raw materials are the locally/ regionally $(<80 \mathrm{~km})$ available menilite, sandstone, and black shales, as well as radiolarite and opal, possibly originating from deposits from the western side of the Eastern Carpathians. Thus, lithic provisioning implies the bulk of long-distance raw material being brought to the site, with negligible local/quasi-local supplying. From a quantitative point of view, secondary debitage products prevail, especially the undetermined items and less than $5 \mathrm{~mm}$ chips/esquilles, alongside cortical and rejuvenation items, and cores/core fragments. Blank production is almost equally split between flakes and laminar products, while retouched implements represent $7.84 \%$ of the assemblage. An attribute-oriented analysis shows dominant percentages of rectilinear profiles, punctiform and flat striking platforms, triangular cross-sections, and unipolar dorsal negatives in both modified and unmodified blanks. Also, quite a few cases of crushed striking platforms and scarred percussion bulbs indicate the use (at least occasionally) of hard hammer percussion.

Among the cortical products, only $4.70 \%$ are primary flakes and blades (100\% dorsal cortex), $33.52 \%$ are secondary flakes, blades, and bladelets (over 50\% dorsal cortex), and 61.76\% are flakes, blades, and bladelets with less than $50 \%$ of the dorsal surface covered in cortex. Most of the rejuvenation products are crested and half-crested blades and bladelets $(81.31 \%)$, alongside few core tablets and debitage surface renewal flakes. Apart from being notably rare within the assemblage, discarded cores and core fragments are heavily reduced and fractured, with multiple debitage surfaces showing mostly hinged flake negatives, and, in one case battered striking surface and small areas of residual cortex. Much like the cortical and rejuvenation products, complete unmodified flakes and blades are rarely over $45 \mathrm{~mm}$ long, with several notable exceptions of 80-120 mm long complete and fragmented laminar products. Formal tools are dominated by burins, marginally retouched blades and bladelets, and backed bladelets, followed by truncated blades, points and several endscrapers. The points category includes shouldered points, pointed bladelets (lamelles appointées), microgravettes, and bilaterally retouched fragments of backed bladelets, susceptible of being former microgravettes; their length and weight values are highly variable, due to fragmentation, while width and thickness values are constant $-3-6 \mathrm{~mm}$ and 2-4 $\mathrm{mm}$ respectively. There are only three complete shouldered points - one $83 \mathrm{~mm}$ long, weighing $3.7 \mathrm{gr}$ and two 29/39 mm long, weighing only 0.4/0.9 gr; possibly, differences in size are related to variable shafts and/or ballistic performances.

The chaine opératoire-based technological approach is somehow difficult to adopt in this case, even when virtually products from all debitage stages are present. For one, the raw material is basically the same for most of the assemblage, which excludes observations related to different strategies of raw material exploitation, depending of accessibility and/or quality. Moreover, the discarded cores are few and barely informative on specific technological strategies of production employed. Nevertheless, flakes and laminar products offer some insights related to technological savoir-faire and intent. Most of the blanks exhibit dorsal negatives indicating the preference for unipolar debitage; few bipolar negatives ( $4.5 \%$ of all blanks) are mainly encountered on rejuvenation products, trapezoidal cross-section laminar blanks and burin spalls. Also, blank's morphology exemplifies at least two levels of knapping proficiency: one employed in producing most of the blanks and tools, including long, slightly concave blades, with parallel straight edges, and one seemingly related to an apprenticeship process ${ }^{37}$. Finally, the formal tool category illustrates a focus on specifically selected blanks - blades and bladelets (one flake being the exception); length and width values are consistently bigger than those of unmodified laminar products, especially for burins and marginally retouched blades, even when fragmented items are considered.

LA2 is the more consistent of the three assemblages, with almost 6000 items, and a large spectrum of long-distance (Cenomanian/Turonian flint, Balkan flint $-3.52 \%$ ), regional (radiolarite, jasper, chalcedony, opal $-28.92 \%$ )

\footnotetext{
${ }^{36}$ Anghelinu et al submitted; Schmidt et al. 2020.

${ }^{37}$ Niță, Cordoș, Anghelinu 2018.
} 
and local (menilite, black shale/schist, sandstone $-51.82 \%$ ) raw materials. Less than $5 \mathrm{~mm}$ chips/esquilles and fragments lacking recognizable stigmas $(63.91 \%$ of the assemblage) are the most numerous for all raw material types. Cortical and rejuvenation products are slightly underrepresented, especially for local raw materials, which could indicate that preparing and shaping of the blocks/nodules took place elsewhere. Rejuvenation products are completely absent for regionally available radiolarite, jasper, and chalcedony, although these raw materials were definitely reduced on site, providing several debitage products for all other technological categories. The heavily reduced cores/core fragments are prismatic and rather small (average length, width and thickness values of 23, 21 , and $15 \mathrm{~mm}$ respectively), with one or two (rarely three) flat striking platforms. The last removals are usually small flakes, with average lengths of $10 \mathrm{~mm}$. The cores are abandoned primarily due to exhaustion/small size, but accidental removals or structural accidents which hinders the reduction process are also present, especially on opal cores. Given the high quantity of flakes and chips for every raw material category, cores are unusually few between $0.5 \%$ and $1.42 \%$ of each category's debitage products, except for a slightly elevated percent of 3.7 for the allogenous Cenomanian/Turonian flint. Moreover, there are no cores for the locally available sandstone, as well as for the more distant types of flint (i.e. Balkan flint). Blank production favors flakes over blades and bladelets, irrespectively of the raw material; among laminar products, bladelets are the most numerous, with average values of 21 (length), 7.5 (width) and 2.7 (thickness) $\mathrm{mm}$. Dorsal negatives indicate a preference for unipolar debitage; most of the striking platforms are flat, with only few cases of dihedral or faceted ones. Formal tools' category mainly includes marginally retouched blades, bladelets, and flakes, followed by backed bladelets, endscrapers, and burins; all in all, $56.11 \%$ of the modified items are bladelets, and $19.4 \%$ are blades. Several of the backed bladelets are truncated (lamelles à dos tronquées), while several others could be defined as microgravettes (small - 15-25 $\mathrm{mm}$ long, light - 0.5-1 gr items, with convergent retouched long edges). A technological reading of the assemblage reveals a pattern of provisioning with mostly local and regional raw materials, followed by one preferential exploitation strategy - unipolar debitage, aimed at obtaining mostly flakes and bladelets. The overall size of the obtained products is rather small, with average lengths slightly over $20 \mathrm{~mm}$; as well, the intensely reduced cores seem to be a specific trait of this assemblage. In fact, this microlithic trend seems to be independent from raw materials distance-related availability or their knapping qualities; more likely, it originated from a particular sociotechnical context ${ }^{38}$.

LA1 is the last securely contextualized and dated assemblage in BL III, with little over 2800 items of various distant (Cenomanian/Turonian, Balkan types of flint, Sita Buzăului chert ${ }^{39}$, obsidian, etc. $-39.72 \%$ ), regional (radiolarite, jasper, chalcedony, opal 12.66\%), and local (sandstone, black shale, menilite $-42.18 \%$ ) raw materials. Undetermined items and less than $5 \mathrm{~mm}$ chips/esquilles account for slightly over half of the assemblage; unmodified flakes, blades, and bladelets form the next most numerous groups, while cores, cortical and rejuvenation products and formal tools are clearly underrepresented. Prismatic, 25-27 mm long, 24-39 mm wide, 20-37 mm thick cores and core fragments exhibit one or two opposite/adjacent striking platforms, and, in one case, residual cortical areas; during the final stages of the reduction sequence semicircular or frontally located debitage surfaces provided short and narrow blades or bladelets and occasionally, flakes. Cores or core fragments of allogenous types of flint or local black shales/schist are absent. Cortical products (less than $50 \%$ dorsal cortex) are more numerous than primary and secondary items (50-100\% dorsal cortex), possibly because, for most of raw material types, the initial stages of the debitage sequence did not take place on the spot. Rejuvenation products are mostly crested and halfcrested blade and bladelets, followed by few core tablets and debitage surface renewal flakes; surprisingly, such products are absent in the case of some local and regional raw material types, despite the consistent presence of flakes and less than $5 \mathrm{~mm}$ chips/esquilles of the same types. Unmodified blanks production provided mainly flakes, while within the laminar blanks, bladelets are the most numerous. Triangular cross-sections and rectilinear/slightly concave profiles prevail, as well as the flat striking platforms, occasionally accompanied by cracked or scarred bulbs. Blades and bladelets are 30 to $50 \mathrm{~mm}$ long, 12 to $20 / 4$ to $10 \mathrm{~mm}$ wide, and 3 to $8 \mathrm{~mm}$ thick; bladelets' dorsal negatives attest to the use of unipolar debitage. Formal tools represent only $1.49 \%$ of the assemblage; most of them belong to distant and regional raw material types, and only several can be ascribed to local types. Rectilinear, 20-30 $\mathrm{mm}$ long backed bladelets form the most numerous group, followed by partially retouched/truncated undetermined fragments, rectilinear/slightly concave $20-40 \mathrm{~mm}$ long marginally retouched or truncated blades and bladelets, only few double/dihedral burins, endscrapers and a single partially retouched flake; also, a single point is represented by a fragmented backed blade, with convergent retouched long edges. As was the case for the previous assemblage, the quantitative/qualitative analysis reveals a lithic production of mostly flakes and bladelets, obtained through unipolar debitage, and a formal tool kit dominated by backed bladelets, with considerably few endscrapers and burins. Unlike the previous case, almost equal amounts of local and allogenous raw materials were exploited, the latter including also Central European obsidian ${ }^{40}$.

\footnotetext{
${ }^{38}$ sensu Högberg, Lombard in press.

${ }^{39}$ A. Ciornei, pers. comm.

${ }^{40}$ C. Bonsall, pers. comm.
} 


\section{Discussion}

All the observations above are of course preliminary, as only a small part of the site has been excavated so far. For instance, the very small excavated area for LA1 may explain, as a simple topographic bias, some features, like the lack of cores from local raw materials. Such shortcomings are nonetheless the norm for most lithic assemblages, as few Palaeolithic settlements were ever fully excavated. Granting these limits, there are consistent differences between the three assemblages that beg for explanations.

The LA1/Gravettian stands apart from the other two assemblages from basically all points of view: (1) a massive focus on high quality imported raw material (flint), apparently brought as complete nodules from distant areas, (2) a carefully mastered unipolar technology focused on the production of laminar blanks, (3) a limited, peculiar typological spectrum based on selected blade/bladelets blanks (burins, retouched blades, backed implements, shouldered points), and (4) a large number of retouched implements, which is apparently not directly related to severe raw material economy (e.g. the large number of fresh blanks left on the spot). Put differently, the amount of retouch is rather related to shaping "specially designed" hafted implements than to recycling/curation. The exhausted flint cores may also be related to the documented apprenticeship activity.

The two Epigravettian assemblages (LA2 and LA3) provide a different picture. The consistently smaller amount of exotic raw materials is supplemented by a high diversity of local and regional raw materials. Apparently, as the lack of cortical elements indicates, the initial preparation of the cores, including those in local raw material, took place elsewhere. The unipolar reduction aims at producing mostly flakes and bladelets, and the average size of the blanks and of the resulting formal tools are much smaller. The latter aspect cannot be correlated to the size or shape of the natural boulders of raw material, for at least local raw materials (black shales, sandstone, menilite) are available in large sizes. In fact, in any of the three assemblages the raw material does not seem to condition the technological options or range of products, despite the obviously different provisioning patterns. The intensity of core reduction seems higher in the LA2 and LA3, despite the dominance of readily available local and regional raw materials. The number of retouched implements is, however, several times smaller in the Epigravettian assemblages than in the preceding Gravettian, suggesting among others that producing additional/using fresh blanks was far more important than retouching/recycling.

The meaning attached to the variability exhibited by these assemblages obviously depends on the question asked and on the available means for answering them. If the "cultural identity" of the makers is sought for, the assemblages clearly belong to the large families of contemporary industries identified in Eastern Romania, Moldavia and Western Ukraine as Molodovian/Gravettian, early Epigravettian and Epigravettian ${ }^{41}$, respectively, with all the ambiguities involved in such formal resemblance. Furthermore, the diachronic variability recorded at Bistricioara seems important enough to indicate "population changes". Behind this truism (given the vast temporal distance separating these occupations), lies of course the 'real' issue: the survival or disappearance of certain "ways of doing" things, the tempo and the mechanism behind them. Put differently, what explains the differences recorded between the Gravettian, early Epigravettian and later Epigravettian assemblages? Was there a swift (population replacement) or rather slow/stochastic drift like change inside the regional paleodeme? For obvious reasons, answering these questions based on three assemblages only entails a lot of qualitative considerations, if not plain speculations. Whatever the case, read from a "classical" synthetic (and not necessarily French) perspective, with its preoccupation for distant, high quality raw materials, demanding technology, distinct savoir-faire, clear focus on big blades, burins and projectiles etc., LA1 (Gravettian) assemblage as a "whole" is qualitatively and thus 'culturally' distinct from the LA2 and LA3 (Epigravettian) layers. It would be however unfair to equate the French lithic endeavours, at least from 1950's on ${ }^{42}$, with such a naive appeal for ready-made cultural-historical explanation. In fact, the contrast between the Gravettian at Bistricioara-Lutărie III and the more expedient early Epigravettian at the same site suggests a range of complex behavioural changes (see below), fully comparable, for instance, with those recorded by French researchers in the transition from Solutrean to Badegoulian ${ }^{43}$, which apparently involved a different spatial organization of technology, a contrasting territorial conceptualisation and use, a changed balance between "domestic" and "hunting" gear etc. A larger regional sample of chronologically close assemblages may help following this line of thinking and check it against the Eastern Carpathians archaeological record.

A functional/adaptive (Anglophone) perspective on the same assemblages also provide promising research avenues. For instance, the balance between "provisioning places/individuals" ${ }^{\text {"44 }}$ seems particularly interesting

\footnotetext{
${ }^{41}$ Noiret 2009; Anghelinu, Niță, Murătoreanu 2018.

${ }^{42}$ Sackett op cit.

${ }^{43}$ Renard, Ducasse 2015. Note that the authors refrain from explicitly equating these sharp and consistent changes to a population break, invoking in the same time a more complex adaptive adjustment.

${ }^{44}$ Kuhn 1994; Kuhn 2004.
} 
for these assemblages. The Gravettian assemblage documents a massive transfer of distant raw material, but despite the high number of retouched items, there are no unambiguous traces of economizing behaviour. As in other cases ${ }^{45}$, this apparently wasteful behaviour can be correlated either to a short duration camp and/or to an attempt at provisioning a special place in the landscape with lithic supplies in anticipation of further occupations. This may further suggest a certain familiarity with the area and some form of tethered nomadism. On the other hand, the Epigravettian assemblages, especially LA1, display much wider provisioning ranges for exotic rocks, relying at least in part on provisioning individuals or on the down the line/distance-decay supplying (e.g. obsidian, Balkan flint, present as small blanks only); it may also indicate longer-term occupation(s), in which local/regional resources became increasingly used.

For the latter aspect, another (Anglophone) quantitative perspective may help defining the occupation character behind the accumulation of these lithic assemblages along the curation/expedient continuum. With (1) large assemblages/few retouched items, (2) a flake-and-bladelets based, rather expedient lithic production, started from already preformed blocks/nodules, and (3) a minimal investment in typological (thus functional?) variability, the Epigravettian assemblages, especially the early Epigravettian (LA2), may indicate central places in a logistical mobility system ${ }^{46}$. The smaller Gravettian assemblage, with clearly defined expert and novice levels of technological proficiency, and a considerably high number of retouched items, mostly burins, large blades and backed implements, points in turn either to residential mobility or to a specialized temporary camp which involved at least one young novice. In all cases, "effective lithic scarcity" was reduced either by massive place provisioning (Gravettian) or by local and regional embedded procurement (Epigravettian). The strongly reduced cores in the early Epigravettian apparently go counter this interpretation, but as both local and regional raw materials are involved, their "curation" is likely not connected to raw material economy, but to the size of microlithic blanks targeted.

A huge amount of additional contextual data is obviously needed for the comprehensive characterization of these lithic assemblages (or any other, for that matter). However, the examples above are hopefully enough to highlight the many complementary information that can be gained by looking at the same data from multiple, analytic or synthetic, perspectives.

\section{Concluding thoughts}

Apart from the pragmatic, techno-functional aspects directly or indirectly approached above (mobility and territorial ranges, raw material provisioning patterns, technological inertias, ideal blanks and functional shapes/uses etc.), many other social and symbolic aspects are likely aggregated under the impersonal taxonomic labels of Gravettian or Epigravettian. Climbing up on Hawkes' ladder of inference require imaginative means and it is unlikely that a single type of approaches - analytic or synthetic - can make sense of all the information and meanings inscribed into lithics. Our main point, however, is that any interpretation of a lithic assemblage undoubtedly benefits from using both family of approaches combined. Quantitative and interpretative analysis do not have to be mutually exclusive - one might as well could quantify interpretations, and interpret quantifications in the same endeavour. If this may indeed sound ambiguous, dialogical and very "French", it is worth reminding, for a proper balance, a crucial aspect insistently stressed by the Anglophone lithic research tradition (and admittedly not truly touched upon here): given the time needed for their accumulation, the emergence of lithic assemblages is a scale-dependent phenomenon $^{47}$. When laid on the archaeologists' study tables, lithic assemblages are thus a motley crew of learned (and therefore not necessarily optimal) technical behaviours, contextual choices, past activities, symbolic loads, natural formation processes, archaeological sampling biases etc. That is, both the French silent ideal - culture written in stones - and the American ideal - (environmental) adaptation written in stones - are likely equally far from such an aggregated reality. Abandoning the tempting "snapshot" image of lithic assemblages in the favour of a more dynamic view on the formation processes seems the only productive way for a proper archaeological assessment of Palaeolithic lithic toolkits. For this purpose, both traditions of research entertain valuable ideas and excellent analytic tools that can be used complementarily. "Hunting" and "gathering" these intellectual resources while keeping an eye on their inevitable biases will clearly lead to a richer understanding of Palaeolithic times.

\footnotetext{
$\overline{{ }^{45} \text { Moreau, Brandl, Nigst } 2016 .}$

${ }^{46}$ Barton, Riel Salvatore op cit; Burke, Riel-Salvatore, Barton 2018.

${ }^{47}$ Shott op cit; Barton, Riel Salvatore op cit; Kuhn 2013.
} 


\section{REFERENCES}

Andrefsky 2005

Anghelinu 2003

Anghelinu 2006

Anghelinu, Niță 2009

Anghelinu, Niță, Murătoreanu 2018

Anghelinu et al. submitted

Bar Yosef, Van Peer 2009

Barton, Neeley 1996

Barton, Riel-Salvatore 2004

Barton, Riel-Salvatore 2014

Burke, Riel-Salvatore, Barton 2018

Clark 2009

Clark, Lindly 1991

Coudart 1999

Dibble 1995

Féblot-Augustins 2009

Fitzhugh 2001

Gao 2013

Hayden 2015

Hiscock 2009
Andrefsky, Jr., W., Lithics: Macroscopic Approaches to Analysis, Cambridge University Press: Cambridge, 2005.

Anghelinu, M., Evoluția gândirii teoretice în arheologia din România. Concepte și modele aplicate în preistorie, Editura Cetatea de Scaun: Târgoviște, 2003.

Anghelinu, M., O paleontologie a „omului etern”; arheologia paleoliticului în România, Cercetări Arheologice, XIII, 2006, 135-158.

Anghelinu, M., Niță, L., La place de la pierre dans l'Âge de la pierre; la perspective de la documentation dans la recherche du Paléolithique, Annales de l'Université Valahia de Târgoviște, XI, 1, 2009, 99-119.

Anghelinu, M., Niță, L., Murătoreanu, G., Le Gravettien et l'Épigravettien de l'Est de la Roumanie: une réévaluation, L'Anthropologie, 122, 2, 2018, 183-219.

Anghelinu, M., Händel, M., Niţă, L., Cordoș, E. C., Vereș, D., Hambach U., Murătoreanu, G., Ciornei, A., Mănăilescu, C., Ilie, M., Demay, L., Georgescu, V., in press, From Gravettian to Epigravettian in the Eastern Carpathians: Insights from Bistricioara-Lutărie III, Quaternary International, submitted.

Bar-Yosef, O., Van Peer, P., The Chaîne Opératoire Approach in Middle Paleolithic Archaeology, Current Anthropology, 50, 1, 2009, 103-131.

Barton, C. M., Neeley, M. P., Phantom cultures of the Levantine Epipaleolithic, Antiquity, 70, 267, 1996, 139-147.

Barton, C. M., Riel-Salvatore, J., Late Pleistocene technology, economic behaviour, and land-use dynamics in Southern Italy, American Antiquity, 69, 2, 2004, 257-274.

Barton, C. M., Riel-Salvatore, J., The formation of lithic assemblages, Journal of Archaeological Science, 46, 2014, 334-352.

Burke, A., Riel-Salvatore, J., Barton, C. M., Human response to habitat suitability during the Late Glacial Maximum in Western Europe, Journal of Quaternary Science, 33, 3, 2018, 335-345.

Clark, G. A., Accidents of history: conceptual frameworks in palaeoarchaeology, in Camps, M., Chauhan, P. (eds.), Sourcebook of Paleolithic Transitions, Springer: New-York, 2009, 19-41.

Clark, G. A., Lindly, J., Paradigmatic biases and Paleolithic research traditions, Current Anthropology, 32, 1991, 577-587.

Coudart, A., Is post-processualism bound to happen everywhere? The French case, Antiquity, 73, 279, 1999, 161-167.

Dibble, H., Middle Paleolithic scraper reduction: background, clarification, and review of the evidence to date, Journal of Archaeological Method and Theory, 2, 1995, 299-368.

Féblot-Augustins, J., Revisiting European Upper Paleolithic raw material transfers: the demise of the cultural ecological paradigm?, in Adams, B., Blades, B. S. (eds.), Lithic Materials and Paleolithic Societies, Blackwell Publishing Ltd, 2009, 25-46.

Fitzhugh, B., Risk and Invention in Human Technological Evolution, Journal of Anthropological Archaeology, 20, 2001, 125-167.

Gao, X., Paleolithic cultures in China. Uniqueness and divergence, Current Anthropology, 54, 2013, 358-370.

Hayden, B., Insights into early lithic technologies from Ethnography, Philosophical Transactions of Royal Society B, 370, 20140356.

Hiscock, P., Reduction, recycling, and raw material procurement in Western Arnhem land, Australia, in Adams, B., Blades, B. S. (eds.), Lithic Materials and Paleolithic Societies, Blackwell Publishing Ltd, 2009, 78-93. 
Hiscock 2014

Högberg, Lombard in press

Holdaway, Douglas 2011

Hovers, Belfer-Cohen 2018

Hussain 2019

Ioviță, McPherron 2011

Kelly 2013

Kohl 1981

Kuhn 1994

Kuhn 2004

Kuhn 2013

Kuhn, Stiner 2001

Meignen, Delagnes, Bourguignon 2009

Moreau, Brandl, Nigst 2016

Niță, Cordoș, Anghelinu 2018

Noiret 2009

Olsen 2012

Perlès 2016

Pfaffenberger 1992
Hiscock, P., Learning in lithic landscapes: a reconsideration of the hominid „toolmaking” niche, Biological Theory, 9, 2014, 27-41.

Högberg, A., Lombard, M., „I can do it” becomes „We do it”: Kimberly (Australia) and Still Bay (South Africa) points through a socio-technical framework lens, Journal of Paleolithic Archaeology, https://doi.org/10.1007/s41982-019-00042-4

Holdaway, S., Douglass, M., A twenty-first century archaeology of stone artifacts, Journal of Archaeological Method and Theory, 19, 2012, 101-131.

Hovers, E., Belfer-Cohen, A., Are lithics and fauna a match made in (prehistoric) heaven?, Journal of Paleolithic Archeology, https://doi.org/10.1007/s41982-0180007-9, 2018.

Hussain, S. T., The French-Anglophone divide in lithic research. A plea for pluralism in Palaeolithic archaeology, Leiden University: Leiden, 2019.

Ioviță, R., McPherron, S. P., The handaxe reloaded: a morphometric reassessment of Acheulian and Middle Paleolithic handaxes, Journal of Human Evolution, 61, 2011, 61-24.

Kelly, R. L., The lifeways of hunter-gatherers. The foraging spectrum, Cambridge University Press: Cambridge, 2013.

Kohl, P. L., Materialist approaches in prehistory, Annual Review of Anthropology, 10, 1981, 89-118.

Kuhn, S. L., A formal approach to the design and assembly of transported toolkits, American Antiquity, 59, 1994, 426-442.

Kuhn, S.L., Evolutionary perspectives on technology and technological change, World Archaeology, 36, 2004, 561-570.

Kuhn, S. L., Questions of Complexity and Scale in Explanations for Cultural transitions in the Pleistocene: A Case Study from the Early Upper Paleolithic, Journal of Archaeological Method and Theory, 20, 2013, 194-211.

Kuhn, S. L., Stiner, M. C., The antiquity of hunter-gatherers, in Panter-Brick, C., Layton, R. H., Rowley-Conwy, P. A. (eds.), Another Day, Another Camp: An Interdisciplinary View of Hunter-gatherers, Cambridge University Press: Cambridge, 2001, 99-142.

Meignen, L., Delagnes, A., Bourguignon, L., Patterns of lithic material procurement and transformation during the Middle Paleolithic in Western Europe, in Adams, B., Blades, B. S. (eds.), Lithic Materials and Paleolithic Societies, Blackwell Publishing Ltd, 2009, 15-24.

Moreau, L., Brandl, M., Nigst, P., Did prehistoric foragers behave in an economically irrational manner? Raw material availability and technological organisation at the early Gravettian site of Willendorf II (Austria), Quaternary International, 406, A, 2016, 84-94.

Niță, L., Cordoș, C., Anghelinu, M., Apprenticeship lithic debitage. Examples from a 27.3 ka cal BP Gravettian collection from Bistricioara-Lutărie III (Ceahlău Basin, NE Romania), Studii de Preistorie, 15, 2018, 13-27.

Noiret, P., Le Paléolithique supérieur de Moldavie, ERAUL 121: Liège, 2009.

Olsen, B., After interpretation. Remembering archaeology, Current Swedish Archaeology, 20, 2012, 11-34.

Perlès, C., La technologie lithique, de part et d'autre de l'Atlantique, Bulletin de la Societé préhistorique française, 113 (2), 2016, 221-240.

Pfaffenberger, B., Social Anthropology of Technology, Annual Review of Anthropology, 21, 1992, 491-516. 
Renard, Ducasse 2015

Richter 2000

Sackett 1991

Schmidt et al. 2020

Shott 2010

Torrence 2001

Villa et al. 2018

Witmore 2014
Renard, C., Ducasse, S., De la rupture typologique à la fracture socio-économique. Implications sur les systèmes de mobilité entre Solutréen récent et Badegoulien dans le Sud-Ouest français (24-21 ka cal. BP), in Naudinot, N., Meignen, L., Binder, D., Querré, G. (eds.), Les systèmes de mobilité de la Préhistoire au Moyen Âge, Éditions APDCA, Antibes, 2015, 193-208.

Richter, J., Social memory among late Neanderthals, Orschiedt, J., Weniger, G. C. (eds.), Neanderthals and Modern Humans - Discussing the Transition. Central and Eastern Europe from 50.000-30.000 B.P., Mettmann: Köln, 2000, 30-41.

Sackett, J. R., Straight Archaeology French Style: The Phylogenetic Paradigm in Historic Perspective, in Clark, G.A. (ed.), Perspectives on the Past: Theoretical Biases in Mediterranean Hunter-Gatherer Research, University of Pennsylvania Press: Philadelphia, 1991, 109-139.

Schmidt, C., Anghelinu, M., Hambach, U., Vereș, D., Lehmkuhl, F., Reassessing the timeframe of Upper Palaeolithic deposits in the Ceahlău Basin (Eastern Carpathians, Romania): Geochronological and archaeological implications, Quaternary Geochronology, 55, 2020, 101020.

Shott, M. J., Size dependence in assemblage measures: essentialism, materialism, and "SHE" analysis in archaeology, American Antiquity, 75, 4, 2010, 886-906.

Torrence, R., Hunter-gatherer technology: macro- and microscale approaches, in Panther-Brick, C., Layton, R. L., Rowley-Conwy, P. (eds.), Hunter-gatherer. An Interdisciplinary Perspective, Cambridge University Press: Cambridge, 2001, 73-98.

Villa, P., Pollarolo, L., Conforti, J., Marra, F., Biagioni, C., Degano, I., Lucejko, J. J., Tozzi, C., Pennacchioni, M., Zanchetta, G., Nicosia, C., Martini, M., Sibillia, E., Panzeri, L., From Neandertals to modern humans: New data on the Uluzzian, PLoS ONE, 13, 4, 2018, e0196786.

Witmore, C., Archaeology and the New Materialisms, Journal of Contemporary Archaeology, 1.2, 2014, 203-246.

MIRCEA ANGHELINU, „Valahia” University of Târgoviște, mircea_anghelinu@yahoo.com

LOREDANA NIȚĂ,

„Valahia” University of Târgoviște, loredana_nita2003@yahoo.com

CRISTINA CORDOȘ,

Institutul de Arheologie, Iași, elenacordos@gmail.com 